\title{
Feminizam i žene beat-generacije
}

\section{Abstract: Feminism and Women of the Beat Generation}

For many years literary theorists considered that women writers of the Beat Generation were not worth mentioning. Being present and absent at the same time, these women remained invisible in popular as well as academic reviews in the Beat Generation literature until the nineties. Today, however, it is crystal clear that the literature of the Beats, even with its distinct misogynistic features, had strong influence on several generations of women writers and artists who have written and performed within the feminist frame. Here we will discuss the women of the Beat Generation who in the early sixties, as insiders within a seemingly male group, started expressing themselves within feminist discourses, through which they sought to free women from the socially imposed roles. The main weapon of the Beat Generation's fight against globalization, conformism, and class inequalities was the freedom of mind, and this particular mind of beatniks was used by women Beat writers in order to question the social model of gender and sex. By overtaking the spirit of defiance and resistance of the Beats, these authors assigned a new meaning to the term $B$ eat by breaking the mainly masculine definition of the Beat Generation.

Keywords: Beat Generation/beat-culture, women Beat writers, popular culture, provocation with aesthetic effect, protofeminism, second-wave feminism

Beatničko književno stvaralaštvo i njihove fizičke akcije u svojoj suštini odgovor su rastućoj globalizaciji, hegemoniji Sjedinjenih Američkih Država, političkom i društvenom konformizmu, etničkim, seksualnim i klasnim nejednakostima, posebice konzumerizmu i medijskom ludilu. Istovremeno, kreativnošću su odgovarali na spoznaje o kulturnim raznolikostima kojima su svjedočili na svojim putovanjima i susretima s lokalnim umjetnicima, nastavljajući se na sve uočene natruhe otpora na koje su nailazili i vidjeli ih u popularnoj kulturi, etničkim manjinama te djelima 
ostalih disidentskih pisaca i avangardnih umjetnika u Americi, ali i izvan nje (Grace i Skerl 4). Naziv beat-generacija danas na različite načine koriste teoretičari književnosti, sociolozi, povjesničari, istraživači i komentatori. Za neke ovaj izraz podrazumijeva cjelokupnu kulturu mladih u razdoblju prvih nekoliko poslijeratnih desetljeća u Americi. Za druge izraz ima uže značenje i odnosi se na grupu određenih autora - pjesnika, sanjara i alternativaca čije je književno i kulturno djelovanje odraz svjesne odluke da se pobune i daju jasan odgovor na nazadnu politiku i stil života američke vladajuće klase i dijelova srednje građanske klase, ali i reakcija na konzervatizam u umjetnosti četrdesetih i pedesetih godina 20. stoljeća u Americi (Sterrit 1-2; Miles 6). Različita tumačenja javljaju se već prilikom pokušaja određivanja pripadnika beat-generacije, pa ćemo tako jednu od najužih definicija pripadnika beat-generacije pronaći kod dubrovačkog pjesnika, slikara, novinara i trenutačno vjerojatno najplodnijeg hrvatskog prevoditelja Voje Šindolića, kojemu je Allen Ginsberg beat-generaciju definirao kao radove Williama S. Burroughsa i Jacka Kerouaca između 1945. i 1955. godine (Šindolić 12). Ann Charters ističe kako je uvijek postojala određena nedoumica kada je riječ o pitanju tko su zapravo bili pripadnici beat-generacije. Naime, u kreativnoj gužvi rastućeg književnog podzemlja ${ }^{1]}$ pedesetih i šezdesetih godina 20. stoljeća pisci nisu bili usko ili neraskidivo povezani s bilo kakvim školama ili utjecajima (Beat Down xxxiv-xxxvi) te se, s vremenom, uska definicija koju nam prenosi Šindolić proširila. Donald M. Allen u svojoj utjecajnoj antologiji The New American Poetry (1960.) pjesnicima beat-generacije nazvao je Jacka Kerouaca, Allena Ginsberga i Gregoryja Corsa, kojima su se pridružili Gary Snyder, Philip Whalen „i drugi u javnim čitanjima poezije" (xi-xiv). Thomas Parkinson u svojoj antologiji A Casebook on the Beat (1961.) zaključio je da je karakteristična beatnička poetika u San Franciscu postojala i prije nego što su se Ginsberg i Kerouac pojavili na tom području pa je, neopterećen geografskim određenjima i govoreći o drugom valu buđenja književnog života na području San Francisca, prilično točno u krug beatnika mogao uključiti i autore kao što su Lawrence Ferlinghetti, Gary Snyder, Philip Whalen i Michael McClure (284-285). Edward Halsey Foster pak izdvaja četiri značajna beatnička pisca, Williama S. Burroughsa, Gregoryja Corsa, Allena Ginsberga i Jacka Kerouaca, no odmah potom skreće pozornost i na tri autora s kojima su beatnici bili usko povezani i koji su izrazito utjecali na njihov rad. To su Neal Cassady, Herbert Huncke i Carl Solomon (Understanding the Beats 1). 
Zanimljivo, već površno gledajući prethodno navedene definicije pripadnika beat-generacije uočljiv je izostanak ženskih imena. Istina, djela koja su definirala beat-generaciju, kao što su Kerouacov roman On the Road (Na cesti; Na putu, 1957.), zbirka pjesama Howl and Other Poems (Urlik i druge pjesme, 1956.) Allena Ginsberga i Naked Lunch (Goli ručak; Goli obrok, 1959.) Williama Burroughsa, otvoreno su izazivala prevladavajuću klimu rasizma i homofobije u Sjedinjenim Američkim Državama pedesetih godina dvadesetog stoljeća, no čitatelji su istovremeno svjedočili i da ovi pisci žene prikazuju isključivo u tradicionalnim rodnim ulogama ${ }^{2]}$ (Johnson i Grace ix). Posljedično, dugi niz godina ne samo čitatelji već i teoretičari u akademskim krugovima smatrali su da ne postoje, ili makar nisu vrijedne spomena, žene unutar krugova beat-generacije. Kako je to sažela Amy Friedman: „Desetljećima je bila ignorirana ionako tek površno opažena prisutnost ženskih pisaca povezanih s beat-generacijom", (229). Čak i kada je njihova prisutnost prepoznata, bio je marginaliziran njihov značaj. Istovremeno prisutne i odsutne, spisateljice beat-generacije tako su ostale nevidljive kako u popularnim, tako i u znanstvenim prikazima književnosti beatgeneracije, njihova utjecaja na američku kulturu te doprinosa američkoj književnoj tradiciji. Kada nisu bile potpuno ignorirane, žene povezane s beat-generacijom bile su odbačene i etiketirane privjescima bez vidljivog doprinosa muškim pripadnicima, beatničkim gropupie djevojkama, a nipošto pravim i ravnopravnim pripadnicama beat-generacije (Carden xi).

Feminizam drugog vala, koji je započeo kasnih šezdesetih godina dvadesetog stoljeća, pojavio se nakon objave najznačajnijih djela Kerouaca, Ginsberga i Burroughsa. lako je već 1970. u knjizi Sexual Politics Kate Millet prozivala mizogàmične prikaze žena u djelima Normana Mailera, koji je u tadašnje vrijeme često povezivan s beatnicima, trebalo je proći još dvadesetak godina feminističke književne kritike prije no što se započela pridavati ozbiljnija pažnja kompleksnoj ulozi beatničkih spisateljica. Zanimljivo je usporediti: kada su se beatnici tek pojavili, postali su meta oštrih napada, kako kritičara iz konvencionalnih znanstvenih časopisa, tako i onih iz dnevnoga tiska. Svi oni našli su se zgroženi društvenim i stilskim provokacijama pisaca beat-generacije. Napadi pak novijeg datuma, oni feminističke kritike, bili su gotovo jednako burni. Danas je ipak prilično jasno kako su muškarci beat-generacije bili osjetljiviji na intelektualne potrebe žena u svojoj sredini nego što su mnogi drugi muškarci njihove generacije bili osjetljivi na potrebe žena s kojima su radili i živjeli (Johnson i Grace ix-x). U prilog tome, iako je položaj žena unutar beatničkog 
pokreta bio česta meta kritičara beat-generacije, govore i same žene koje su se kretale u njihovim krugovima zdušno podupirući beatnički pokret. Već memoari spisateljica beat-generacije pružili su tako neke nove uvide u beatničku povijest iz ženskog ugla. Minor Characters (1983.) Joyce Johnson knjiga je koja prikazuje autoričin dolazak u New York i s posebnom pažnjom osvrće se na ljubavnu vezu s Kerouacom. Hettie Jones, jedna od urednika beatnicima bliskog časopisa Yugen (1958.-1962.), objavila je How I became Hettie Jones (1990.), priču o njezinu ljubavnom odnosu s LeRoijem Jonesom. Carolyn Cassady napisala je 1976. godine Heart Beat, a 1990. Off the Road, knjige u kojima je rasvijetlila svoje odnose s Nealom Cassadyjem, Jackom Kerouacom i Allenom Ginsbergom. Beat-generaciju istraživale su i znanstvenice kao što su Ann Charters, urednica knjige The Beats: Literary Bohemians in Postwar America (1983.), koja je napisala i Kerouacovu biografiju (Lawlor xvii). Ostale istraživačice beat-generacije obuhvaćaju u znanstvenoj zajednici značajna imena kao što su Jennie Skerl, Helen Vendler, Regina Weinreich, Ann Douglas, Hillary Holladay i druge.

Proučavajući život i djelo spisateljica koje su se kretale u krugu ili na marginama beat-generacije, na neki način otvaramo i proširujemo uvriježenu definiciju beat-generacije te pojmu dodjeljujemo novo značenje u okviru šireg razumijevanja književnih praksi, diskursa i djelovanja pokreta, istovremeno razbijajući u književnom i povijesnom pogledu još uvijek dominantnu jednoznačnu maskulističku definiciju[?] Ženska prisutnost u beatničkom pokretu tek je s vremenom postala vidljivija. Žene doista jesu bile prisutne, i to od samih početaka, no „u debeloj sjeni muških pripadnika generacije, transformirajući značenje vlastitog prisustva u posve marginalne okvire" (Johnson, „Mapping” 5), ili kako je to šeretski opisao Kerouac: „Od žena se očekivalo da ne govore ništa i nose crninu", (citirano u Johnson i Grace 1). Njihova imena počet će se pojavljivati usporedo sa širenjem utjecaja i posljedično, redefiniranja samoga značenja pojma beat-generacija i prerastanja generacije u beatnički pokret. Riječ beat, kada je promatramo u uvjetno rečeno širem smislu, vrlo lako može uključiti i pisce iz nešto kasnijeg razdoblja, iz šezdesetih godina. To su primjerice Diane di Prima, LeRoi Jones (Amiri Baraka), Ed Sanders, Clark Coolidge, Anne Waldman, Ken Kessey, Timothy Leary, Richard Farina, Joanna McClure. Pisci su to čija poezija i 
proza jest pod utjecajem beatnika, ili je jednostavno samo vrlo slična njihovoj. Ovdje dakle već govorimo o proširenom značenju termina beat-generacija i beat-kulturi kao pokretu[4]

Oprečni su pogledi kritičara na načine kojima su se žene, beatnice, međusobno podržavale, stvarajući vlastitu književnu zajednicu unutar dominantne muške umjetničke zajednice. Primjerice, Amy L. Friedman smatra kako je njihova međusobna podrška vidljiva u podvojenosti između svakodnevnih zadataka majčinstva i uloga ljubavnica nasuprot umjetničkog djelovanja u kojemu su preuzimale uloge spisateljica i urednica raznih nezavisnih časopisa („Being Here” 239). Johnson i Grace, potpuno suprotno, smatraju kako su se za razliku od muških autora koji su uživali intenzivnu međusobnu podršku kroz različite oblike suradnje, žene u krugu beat-generacije u vlastitom autorskom sazrijevanju osjećale izolirano (Johnson i Grace 17). Ono što je ipak potpuno očigledno jest da kao protofeministice one nisu mogle dostići potreban kulturni zalet za stvaranje zajednice zasnovane na sestrinstvu, kakva bi bila karakteristična za feminizam drugog vala i koja bi njihovo djelovanje osnažila te se čini kako je većina ovih autorica odlučila smatrati se usamljenim istraživačicama, izoliranim pojavama unutar dominantne muške skupine, gotovo uvijek u ulogama pratiteljica i seksualnih partnerica. No ozbiljnije propitkivanje rodno pristrane naravi beatničkog pokreta započelo je tek devedesetih godina 20. stoljeća, kada su određeni radovi autorica feminističke kritike počeli ponovno otkrivati zaboravljene autorice beat-generacije. Muškost beatničke filozofije i uvriježena načela muškosti unutar beatničkog kulturnog prostora bili su toliko duboko utemeljeni da su prije pojave ovih kritičkih radova žene unutar kruga beatgeneracije bile gotovo potpuno zaboravljene. Nisu spominjane čak ni u antologijama i kritičkim osvrtima feministički nastrojenih autora ${ }^{5]}$ (Castelao Gómez 52-53). Zbog toga naglašavamo važnost radova koje ćemo predstaviti u nastavku našega kratkog osvrta, koji su se počeli pojavljivati devedesetih godina 20. stoljeća te predstavljaju prva ozbiljna istraživanja ženskog utjecaja na beat-generaciju i beatnički pokret u cjelini.

Prvo značajnije istraživanje objavila je 1996. godine Brenda Knight pod naslovom Women of the Beat Generation. Ta je knjiga u Sjedinjenim Američkim Državama privukla veliku medijsku pozornost, a značajna je zato što je, podijelivši in u četiri skupine, zapravo prva vrlo jasno odredila pripadnice beat-generacije. Prethodnice su Helen Adam, Jane Bowles, Madeline Gleason i Josephine Miles; muzama su nazvane supruge pripadnika beat-generacije i to su Joan Vollmer 
Adams Burroughs, Carolyn Cassady, Edie Parker Kerouac, Joan Kerouac i Eileen Kaufman. Spisateljice su Mary Fabilli, Diane di Prima, Elise Cowen, Joyce Johnson, Hettie Jones, Joanne Kyger, Denise Levertov, Joanna McClure, Janine Pommy Vega, ruth weiss ${ }^{[6]}$, Mary Norbert Körte, Brenda Frazer, Lenore Kandel, Anne Waldman i Jan Kerouac. Naposljetku, umjetnicama su označene Jay DeFeo i Joan Brown (Women vii-viii). Godine 1997. objavljena je A Different Beat urednika Richarda Peabodyja, prva antologija proze i poezije spisateljica beat-generacije. Antologija obuhvaća radove objavljene nakon 1965., no osim mnogih autorica o kojima je pisala Brenda Knight, dodatno su uvrštene i neke manje poznate autorice koje su na ovaj način dobile prvu priliku za afirmaciju. Između ostalih to su Carol Bergé, Sheri Martinelli, Elise Cowen, Sandra Hochman, Fran Landesman, Laur Ulewicz, Barbara Moraff i Margaret Randall (A Different Beat viiix). Napokon, važno je navesti i dva značajna i u akademskoj zajednici hvaljena istraživanja autorica Ronne C. Johnson i Nancy Grace. Girls Who Wore Black objavljena je 2002. i predstavlja prvi zbornik znanstvenih tekstova o spisateljicama beat-generacije s naglaskom na njihovu poeziju, dok je Breaking the Rule of Cool knjiga intervjua s beatničkim autoricama i objavljena je 2004. godine. Za naš osvrt potonja je ujedno i najznačajnija jer ćemo se, kako bismo u daljnjem tekstu prikazali karakterističnu estetiku spisateljica beat-generacije, koristiti podjelom koju je Ronna C. Johnson napravila u odličnom predgovoru ove knjige, naslovljenom „Mapping Women Writers of the Beat Generation", a u završnom ćemo osvrtu govoriti ponajviše o drugoj generacijij ${ }^{7]}$ beatničkih spisateljica upravo prema njezinoj podjeli, dok ćemo se osvrnuti i na, u kontekstu naše teme, vrlo zanimljivu treću generaciju.

Ronna C. Johnson podijelila je, dakle, spisateljice beat-generacije u tri generacije, što vrlo dobro ocrtava „strukturu koja je odraz dugovječnosti i kontinuiteta utjecaja beatničkog pokreta” (Grace, „Mapping” 8). Tri generacije spisateljica ujedno odgovaraju uvriježenoj podijeli pisaca beatgeneracije na prvu i drugu generaciju, te treću generaciju na tragu ranije spomenute beatničke inkluzivnosti i njihova utjecaja na pop-kulturu, o čemu je govorio Kurt Hemmer. Prvu generaciju spisateljica beat-generacije prema Johnson predstavljaju žene rođene tijekom prvog i drugog desetljeća 20. stoljeća: Madeline Gleason (1903. - 1979.), Helen Adam (1909. - 1992.), Sheri Martinelli (1918. - 1996.), ruth weiss (1928.) i Carol Bergé (1928. - 2006.) te one odgovaraju generaciji Jacka Kerouaca (1922. - 1969.), Allena Ginsberga (1926. - 1997.) i Williama S. 
Burroughsa (1914. - 1997.). Najveća i međusobno povezanija skupina spisateljica pojavila se u drugoj generaciji. Pripadnice druge generacije rođene su tridesetih godina 20. stoljeća, dakle mlađe su od prve beatničke generacije jedno ili više desetljeća te su prve autorice koje su se izravnije suočile s muškim predrasudama prema njihovim kako književnim, tako i buntovničkim kapacitetima. Pripadnice druge generacije su Joanna McClure (1930.), Lenore Kandel (1932. - 2009.), Elise Cowen (1933. - 1962.), Diane di Prima (1934.), Hettie Jones (1934.), Joanne Kyger (1934. - 2017.), Joyce Johnson (1935.), Ann Charters (1935.) i Brenda Frazer (Bonnie Bremser; 1939.). Ove autorice usporedive su s muškarcima druge beatničke generacije, koju predstavljaju Philip Whalen (1923. - 2002.), Lew Welch (1926. - 1971.), Ted Joans (1928. - 2003.), Gary Snyder (1930.), Gregory Corso (1930. - 2000.), Michael McClure (1932.) i LeRoi Jones (Amiri Baraka; 1934. - 2014.). Treća generacija prema Johnson rodno je miješana beatnička generacija koja, nasuprot prvim i drugim beat-generacijama, predstavlja konkretan zajednički doprinos povećanju važnosti ravnopravnosti spolova. Riječ je dakle o trećoj generaciji beatničkog pokreta čiji su pripadnici rođeni tijekom II. svjetskog rata i odrastali tijekom šezdesetih godina 20. stoljeća. To su Ed Sanders (1939.), Bob Dylan (1941.), Jerry Garcia (1942. - 1995.), Lou Reed (1944.), Patti Smith (1946.), Lester Bangs (1948. - 1982.), i Laurie Anderson (1947.), kojima vrlo lako možemo pridodati Janine Pommy Vegu (1942. - 2010.) i Anne Waldman (1945.). Ako su pripadnice druge generacije feminizam drugog vala nagovijestile, onda pripadnici treće generacije predstavljaju kontinuitet povezanosti beatničkog pokreta s hippie pokretom i progresivnim aktivističkim pokretima te ostvaruju nagoviještene naznake feminističkih stremljenja prethodne generacije. Ovi suvremenici nastanka drugog vala feminizma u svojim književnim ostvarenjima ${ }^{[8]}$ žensku slobodu i autonomiju smatrali su nužnima te nisu bili samo promatrači već su njihove riječi dolazile doista iz rovova feminističke borbe („Mapping” 8-18).

Kao što smo vidjeli, iako frustrirane neravnopravnošću vlastitog statusa, žene iz krugova beatgeneracije na neki način sudjelovale su u rodnoj podjeli koja je prožimala društvo te odražavala žensku podčinjenost muškarcima. Takvo sudjelovanje čak i u vremenu prije pojave pokreta za oslobođenje žena na prvi pogled iznenađuje i čini se gotovo nepomirljivim. No doprinos žena beatničkom pokretu odražava se u njihovu pisanju kroz teme prepoznavanja ugnjetavanja žena i 
promišljanja opsega njihove odgovornosti za takvo stanje. Zbog toga njihovo sudjelovanje nije nikakav odraz slabosti, već zapravo vrlo mudro prihvaćanje prilike aktivističkog djelovanja iznutra, gdje je priliku za oslobođenje ženama predstavljala upravo nekonvencionalnost bohemskih enklava poput beatničke. Uostalom, to je na tragu onoga što je napisao Edward Halsey Foster u svojoj knjizi naslovljenoj Understanding the Beats: „Beatnička zabrinutost za samospoznaju i njihovo zanimanje za otkriće metoda oporavka percepcije stvarnosti su ciljevi očito podjednako važni feministicama”, (24).

Otpor ovih autorica marginalizaciji unutar beatničkog pokreta, kao i njihovo opiranje zabranama koje su nametane općenito ženama u poslijeratnoj kulturi, bio je poticaj kritikama artikuliranima prilikom pojave feminizma drugog vala, koji si je za cilj uzeo biti otpor upravo rodnim podjelama s kakvima se žene suočavaju i koje ih čine podčinjenima. Spisateljice beat-generacije prepoznale su ovaj problem vlastitog ugnjetavanja kao vrlo jasnu opasnost i pomogle su u traženju rješenja. Njihovi književni tekstovi tako vrlo izravno upiru prstom u beatničku samouvjerenost, njihovu samoljubivu individualnost, te umjesto takvog samouvjerenog samoljublja zahtijevaju osjećajniju usklađenost za kakvu su smatrale da je potrebna kako bi se postiglo žensko samooslobođenje. $\mathrm{Na}$ neki način protofeministički uzlet žena beat-generacije baš unutar muški nastrojenog beatničkog pokreta jedan je od pokazatelja koji nagovješćuju skorašnji postmodernistički iskorak u umjetnosti i kulturi Sjedinjenih Američkih Država. Doista, spisateljice beat-generacije preteče su ženskih pokreta stasalih u šezdesetim godinama 20. stoljeća, njihove književne intervencije i izričaj oblikovali su i naglasili nužnost društvenih sloboda nasušno potrebnih ženama i njihovoj održivosti u književnosti, a sve to dogodilo se upravo u presudnom trenutku. Gotovo na isti način kao što se u presudnom poslijeratnom trenutku pojavila i sama beat-generacija te potaknula masovnu preraspodjelu društvene svijesti privukavši pozornost javnosti kao kontrakulturni fenomen, njihova pojava uzrokovala je otriježnjenje od prevladavajućih konformističkih shvaćanja doma, obitelji, kao i normativne heteroseksualnosti. Usredotočivši se na seksualnost i rodne razlike, književnost žena beat-generacije problematizirala je rodne podjele, čime su one napravile svojevrstan uvod u upravo nastajuće poslijeratne feminističke teorije. Iz njihovih radova vidljivo je, primjerice, kako se promišljanja pripadnica feminizma drugog vala o ženskim seksualnim slobodama i pravima te njihovi pogledi na ženu kao seksualno biće nisu pojavili krajem šezdesetih godina dvadesetog 
stoljeća ex nihilo, već su posljedica promišljanja (i) žena beat-generacije tijekom protofeminističkog razdoblja (Johnson i Grace 9-10).

Književnice beat-generacije nisu imale priliku dati svoj doprinos značenju pojma beat tijekom razdoblja stvaranja pokreta jer su bile odbačene u korist svakodnevnih beatničkih narativa i tema beatničke književnosti koje i danas prepoznajemo kao prevladavajuće - to su teme seksualnosti, ludila, opscenosti, samoubojstva i društvene neuroze u Americi. Uloge supruga, majki i ljubavnica koje su izvršavale zasjenile su ih kao umjetnice, no one su ušavši u krug beat-generacije počele svojim pisanjem pojam beat mijenjati i pridodavati mu nova značenja. Birajući fragmente onih beatničkih značenja koja su odgovarala njihovoj stvarnosti i društvenim problemima, iskoristile su in u vlastite svrhe na način da izgleda kao da slijede upravo beatnički kodeks, u književnoj teoriji često nazivan the rule of cool. ${ }^{[9]}$ Tako su one promiješale karte na književnoj sceni i revidirale uloge koje su im bile društveno i kulturno uvjetovano dodijeljene, te su započele artikulirati alternativne vizije ženskosti. Može se reći da su književnice beat-generacije iskoristile mogućnosti koje im je pružio fragmentirani karakter beatničkog pokreta kako bi ga obogatile drugačijom vizijom kulture, estetike, retorike, ikonografije i spolne zastupljenosti. Ova praksa subverzije iznutra omogućila im je, u konačnici, ostvariti se kao umjetnice unutar beat-generacije zahvaljujući zanimljivom potezu uspješnog korištenja oružja svojih protivnika u vlastite svrhe (Johnson, „Mapping” 22).

Ovdje je zanimljivo usporediti odnos prema gradu i cesti kao sinonimu za putovanje beatničkih muškaraca i žena. Prva je o tome pisala Janet Wolff u svojem istraživanju važnosti geografskog prostora i specifičnoga urbanog značaja četvrti Greenwich Village u New Yorku te koncepta kretanja i putovanja beat-generacije, no s naglaskom na rodne razlike. Proučavajući američku kulturu pedesetih godina 20. stoljeća, Wolff dolazi do zaključaka o „važnosti alternativnih kultura za mlade žene koje su dovoljno neovisne potražiti načine bijega iz konformizma i idile američkog predgrađa. U takvim projekcijama bijega Greenwich Village predstavljao je pravo prostranstvo, istovremeno simboličko i stvarno mjesto mogućnosti drugačijeg života" (Wolff 141). S obzirom na to da su, već smo se uvjerili, kontrakulture toga vremena bile dominantno „muške, seksističke i najčešće seksualno nazadne" (Wolff 144), žene koje su uspjele doći do svojega urbanog iskustva shvatile su da je njima upravo dolazak u grad i ulazak u krugove gradskih bohemskih skupina 
predstavljao prekid s ideologijom i politikama podjele, omogućivši im u praksi provođenje rekonceptualizacije prostora iz vlastite perspektive. Muškom dijelu beatničkog pokreta, naprotiv, grad je predstavljao u neku ruku samo početnu i krajnju točku te svojevrstan uvod u život na cesti, koja je najčešće spajala New York i San Francisco, no nipošto samo te dvije točke i nipošto samo u Americi.

Proučavajući dalje odnos beatničkih spisateljica prema snu „putovanja na cesti”, Wolff zaključuje da su nomadski subjektivitet i identitet u pokretu iskustva slobode kakva su kulturološki u zapadnoj povijesti utvrđena kao isključivo muška, budući da „žene nikada nisu imale ravnopravan pristup cesti" (Wolff 121). Potvrđuje nam to i Joyce Johnson u svojoj knjizi memoara Minor Characters: „Godine 1957. Jack Kerouac je još uvijek putovao (...). Vrlo brzo bi me napustio i otišao u Tangier... Slušala bih ga s oduševljenjem i boli, gledajući sve slike, tako lijepe, koje je naslikao za mene, htijući poći s njim. Hoće li ikada uključiti ženu u svoja putovanja?" (citirano u Wolff 121). Sam čin napuštanja predgrađa žena ovoga razdoblja stoga predstavlja istu onakvu pobunu, ali i potragu, kakvu su muški pripadnici beat-generacije izražavali svojim putovanjima. To je učinila Diane di Prima napustivši svoj bruklinški dom kako bi otišla na Lower East Side, Pommy-Vega napustila je školu i New Jersey, a Joyce Johnson također je napustila školovanje i roditelje. Jednostavno rečeno, sve one iskoristile su odlazak u gradsko okruženje kako bi se ostvarile kao žene i umjetnice izazivajući društveno nametnute zabrane svojim ulogama gradskih žena. Grad im je pružio mogućnost boriti se, spojiti majčinstvo s kreativnošću tako što su skroz književnost svoju privatnost na posve beatnički način podijelile s ulicom, progovorivši o pelenama i menstruaciji, o intimi tijela i ljubavi (Castelao Gómez 60). One su svoje društveno uvjetovane uloge majke, supruge i ljubavnice živjele uz veliku dozu bohemskih sloboda, kao što su one seksualne, zanimajući se uz to i za hipsterske egzistencijalne brige, te su upravo redefinirajući ulogu žena u društv[10] ${ }^{10]}$ malo-pomalo postajale autentične beatničke spisateljice (Johnson, „Mapping” 26).

Krećući se prema završetku ovoga kratkog osvrta, na primjeru nekoliko autorica prikazat ćemo još kako je uklapanje feminističkog diskursa književnosti ovih žena u okvire beatničke književnosti značajno umanjilo postojeći maskulistički diskurs, deministifirajući rodne pretpostavke o ženstvenosti. ${ }^{[11]}$ 
Roman Come and Join the Dance (1962.) autorice Joyce Johnson sa svojim ženskim bohemskim pogledima na seks, hladnoratovski egzistencijalizam i njujorške hipsterske krugove ističe se gotovo kao originalan beatnički tekst. No ovaj roman, nasuprot maskulistički nastrojenih klasičnih beatničkih tekstova, navješćuje dolazak upravo onih žena koje su u njima redovito marginalizirane. Govoreći o ženskoj seksualnosti ovaj roman donosi beatničkoj književnosti model ženskosti prikazujući transformaciju žena kao objekata u samosvjesne žene. Johnson sa sasvim feminističke pozicije citira klasike američke književnosti i poigrava se žanrom romana ceste dekonstruirajući ga te otvara priliku književnicama beat-generacije simbolički, no vrlo odlučno, izaći iz muške sjene. Izazivajući beatnički maskulistički diskurs prikazom svoje otuđene heroine koja stoji nasuprot sustava, prikazom njezine seksualne slobode, što su sve privilegije dotad rezervirane za muškarce, Johnson upućuje kritiku ustaljenim rodnim kodovima društva. Roman svojim raspletom najavljuje nadolazeće promjene u rodnim ulogama te predviđa pojavu feminizma drugog vala ${ }^{[2]}$ (Johnson, „And Then” 70).

Diane di Prima jedna je od heroina prethodnica feminizma drugog vala i u svojoj poeziji postigla je sasvim jedinstvenu viziju. Danas uglavnom pojednostavljeno smatrana feministicom, nije naodmet naglasiti kako je uvijek izmicala svim granicama pa u neku ruku izmiče i takvom određenju. Sebe je predstavljala, kako osobno, tako i na području pjesničke estetike, kao osobu definiranu muškarcima (Libby 46-47). Doduše to je i sasvim logično: vidjeli smo kako je živjeti kao pjesnikinja beat-generacije pedesetih godina 20. stoljeća gotovo po definiciji značilo biti određena muškim očekivanjima. Ipak je neosporno kako je njezina poezija izvor istraživanja prije svega izrazito feminiziranih tema kao što su ženska seksualnost, rađanje i korištenje tijela u svrhu nasilnog otpora fizičkom i emotivnom nasilju. Ranije u tekstu govorili smo o beatničkom kodu nazvanom the rule of cool i sada je dobra prilika naglasiti kako je riječ o nečemu što je književna kritika gotovo jednoglasno proglasila maskulističkim. Naime, ovaj je kod poslužio (i) kako bi se „duplicirala ženska nemoć i njihova objektivizacija, osigurala tišina ženskoga spola (...)” (Johnson i Grace 8). No u svojim alegorijskim memoarima, Memoirs of a Beatnik (1969.), primjena tog koda di Primi omogućuje izbjeći tradicionalno oblikovane modele ženskosti te izmjenu možda i najtradicionalnije ženske uloge - majčinstva. Di Prima tako u svojim memoarima s jedne strane promišlja o svojem odbijanju prihvaćanja uloge rasplodne životinje unutar svoje patrijarhalne obitelji talijanskog 
porijekla u mladosti (35), no isto tako svoje čitatelje potiče na odbacivanje svih oblika kontrole nataliteta kao neprirodnih i opasnih (75). lako sama ne slijedi vlastite savjete, do kraja teksta ona ipak uspijeva ostvariti neku vrstu alternativnih „domaćinstava” (99) u obliku slobodnog, cool majčinstva. Vježbajući istovremeno svoje „seksualne i majčinske vještine” (63), di Prima prelazi granice rodnih uloga, djelujući istovremeno kao obiteljski hranitelj i kuhar, zaštitnik i odgojitelj. U ovakvim kućanstvima bez hijerarhije i obiteljima bez društveno uvjetovanih uloga di Primino majčinstvo dopušta uz brigu o voljenima istovremeno cijeniti i sebe (Carden 43-44). No u našem kontekstu možda je još i važnije spomenuti di Priminu pjesmu „Revolutionary Letter \#66: TO THE PATRIARCHS”, posvećenu Inez Garcia, ženi osuđenoj za ubojstvo muškarca koji ju je silovao i koja je privukla veliku pozornost feminističkih pokreta. Ova pjesma, javno prikazujući tijelo i tjelesnost kao mjesto moguće revolucije i metaforički transformirajući tijelo u oružje ${ }^{13]}$, jasno svrstava autoričin diskurs u okvir radikalnog feminizma drugog vala, čija je agenda između ostalog bila upravo i povezivanje tjelesnosti s idejama nasilne revolucije.

Za kraj ovog kratkog osvrta smatramo nužnim spomenuti i jednu od pripadnica treće beatgeneracije. Naime, Anne Waldman, čiji je duhovni otac bio Allen Ginsberg ${ }^{14]}$, pjesnikinja je nezaobilazna u kontekstu promišljanja veza beatničke književnosti i feminizma. Poezija Anne Waldman primjer je već ispreplitanja osobnog i političkog, što je karakteristično za razdoblje postmodernizma i k tome to je karakteristika uočljiva u oba kulturna pokreta koja su oblikovala njezine stavove i pjesnički izričaj - beatnički pokret pedesetih i, politički još subverzivniji, neofeministički pokret drugog vala šezdesetih i sedamdesetih godina 20. stoljeća. Od beatnika preuzela je Ginsbergove i Burroughsove stilske inovacije kao što su jedinica daha i tehnika rasijecanja te je beatničke kontrakulturne teme proširila i usmjerila prema onim multikulturalnim ${ }^{15]} \mathrm{i}$ feminističkim (Puchek, „From Revolution” 227-28). Odličan primjer poezije potpuno u znaku feminizma, a opet beatnički ostvarene u smislu pjesničke svijesti, jest njezina pjesma „Fast Speaking Woman”, objavljena 1975. u izdanju Ferlinghettijeve izdavačke kuće City Lights i u okviru njihove proslavljene Pocket Poets Series. Ova pjesma temeljena je na šamanskom pjevanju[16] Marie Sabine, pripadnice indijanskog plemena Mazatec koje je Waldman, čuvši ga, okarakterizirala „iskonskim osnaživanjem” (24). S jedne strane svojom strukturom potpuno je nalik Ginsbergovom „Urliku”, no istovremeno se iz nje može iščitati kontrast između muškog beatništva prve generacije 
i beatničkog feminizma druge generacije. Za razliku od di Prime, koja promišlja žensko tijelo kao izvor moći, Waldman u ovoj pjesmi predstavlja koncept poetike tjelesnosti ${ }^{17]}$, što je opet potpuno na tragu beatništva, no ovom prilikom beatnički koncept u službi je ženskoga prosvjetljenja i otpora. Sama pjesma utvrđuje individualne i kolektivne identitete žena, nabrajajući njihove moguće kvalitete, aktivnosti, rase, religije, društvene statuse i zanimanja, sve ono što žene mogu biti kako bi se odredile, kako prema sebi tako i prema vlastitoj ulozi u društvu, dok je naslov pjesme odraz beatničke izvedbene poetike. Naime, riječ je o pjesmi namijenjenoj javnim čitanjima i tek izgovorenoj naglas, pred publikom, udahnut joj je život. Također, riječ je i o zauvijek nedovršenoj pjesmi, pjesmi u nastajanju, improvizaciji kojoj Anne Waldman svakom recitacijom mijenja riječi, oduzima postojeće i dodaje nove, te joj tako daje novi smisao[18]

U konačnici, jasno je kako su tri generacije književnica beat-generacije glasno artikulirale nove, ženske glasove američke književne i kulturne scene, koji će imati zadaću biti protuteža postojećim pretežnim patrijarhalnim književnim diskursima te, preuzevši i prilagodivši moderne eksperimentalne književne oblike, nagovijestiti pojavu neofeminizma. lako in karakterizira prilična raznolikost, većina radova žena beat-generacije ima jednu sličnost koja utjelovljuje ono što je feminizam drugog vala okarakterizirao žensko usredotočenom književnošću - sve ove autorice uzimaju ženu kao polaznu točku te su usredotočene na ženske živote i njihove egzistencijalne brige unutar poslijeratne boheme. One tako isprva pišu o stereotipima sveobuhvatne pasivnosti pripadnica srednje klase i njihovoj seksualnoj frigidnosti tijekom pedesetih godina i dalje, prema oslobođenju ženske seksualnosti i njihovom samoizražavanju. Ova obilježja posebno su značajna za razumijevanje konteksta pojave feminizma drugog vala. Mlađe i više nekonformistički nastrojene čak i od očeva beat-generacije, ove autorice uspješno su pomogle premostiti jaz između dva vrlo važna kontrakulturna pokreta u Americi sredinom dvadesetog stoljeća beatničkog i neofeminističkog. Stavljajući uporno u prvi plan žensko iskustvo tijekom hladnoratovskih pedesetih i hipijevskih šezdesetih godina 20. stoljeća, ali nastavivši to i kasnije, velika zasluga žena beat-generacije ulazak je iskustva rodne disidencije u kulturu i književnost postmodernizma u Americi i šire (Johnson i Grace 22-23). 


\section{Bibliografija}

Allen, Donald M., ur. The New American Poetry. Grove Press, 1960.

Carden, Mary Paniccia. Women Writers of the Beat Era: Autobiography and Intertextuality. University of Virginia Press, 2018.

Castelao-Gómez, Isabel. „Beat Women Poets and Writers: Countercultural Urban Geographies and Feminist Avantgarde Poetics." Journal of English Studies, vol. 14, 2016, pp. 47-72.

Charters, Ann, ur. Beat Down to Your Soul: What Was the Beat Generation?. Penguin Books, 2001.

di Prima, Diane. Memoirs of a Beatnik. Penguin Books, 1998.

---. „Revolutionary Letter \#66: TO THE PATRIARCHS.” Revolutionary Letters, City Lights Books, 1971, p. 85.

Foster, Edward Halsey. Understanding the Beats. University of South Carolina Press, 1992.

Friedman, Amy L. "Being Here as Hard as I Could: Beat Generation Women Writers." Discourse, vol. 20, 1998, pp. 229-44.

Grace, Nancy M. i Jennie Skerl, ur. The Transnational Beat Generation. Palgrave MacMillan, 2012. Hemmer, Kurt, ur. Encyclopedia of Beat Literature. Facts On File, 2007.

Johnson, Ronna C. „And Then She Went: Beat Departures and Feminine Transgressions in Joyce Johnson`s Come and Join the Dance." Girls Who Wore Black: Women Writing the Beat Generation , priredile Ronna C. Johnson i Nancy M. Grace, Rutgers University Press, 2002, pp. 69-95.

---. „Mapping Women Writers of the Beat Generation.” Breaking the Rule of Cool: Interviewing and Reading Women Beat Writers, priredile Ronna C. Johnson i Nancy M. Grace, University Press of Mississippi, 2004, pp. 3-41.

Johnson, Ronna C. i Nancy M. Grace, ur. Girls Who Wore Black: Women Writing the Beat Generation. Rutgers University Press, 2002. 
Knight, Brenda, ur. Women of the Beat Generation: the Writers, Artists and Muses at the Heart of a Revolution. Conari Press. 1996.

Lawlor, William T. Beat Culture: Icons, Lifestyles, and Impact. ABC Clio, 2005.

Libby, Anthony. „Diane di Prima: Nothing Is Lost; It Shines in Our Eyes.” Girls Who Wore Black:

Women Writing the Beat Generation, priredile Ronna C. Johnson i Nancy M. Grace, Rutgers University Press, 2002, pp. 45-68.

Miles, Barry. The Beat Hotel: Ginsberg, Burroughs, and Corso in Paris, 1958 - 1963. Grove Press, 2000.

Parkinson, Thomas, ur. A Casebook on the Beat. Thomas Y. Crowell Company, 1961.

Puchek, Peter. „From Revolution to Creation: Beat Desire and Body Poetics in Anne Waldman`s Poetry." Girls Who Wore Black: Women Writing the Beat Generation, priredile Ronna C. Johnson i Nancy M. Grace, Rutgers University Press, 2002, pp. 227-50.

---. „Semiotics and Creation: Anne Waldman`s `iovis` and Body Poetics.” Literature and Psychology, vol. 49, no. 1-2, 2003, pp. 39-64.

Quinn, Roseanne G. „The Laugh of the Revolutionary: Diane diPrima, French Feminist Philosophy and the Contemporary Cult of the Beat Heroine." The Philosophy of the Beats, priredila Sharin N. Elkholy, The UP of Kentucky, 2012, pp. 19-32.

Sterrit, David. Mad to be Saved: the Beats, the `50s, and Film. Southern Illinois UP, 1998.

Šindolić, Vojo. Jazz: Beat. O utjecaju jazza na djela Beat generacije i obrnuto. Ex libris, 2017.

Waldman, Anne. „Fast Speaking Woman.” Fast Speaking Woman: Chants \& Essays, City Lights Books, 1975, pp. 3-43.

Wolff, Janet. Resident Alien: Feminist Cultural Criticism. Yale, 1995. 
[1] Engl. underground, dakle prije svega prijevod koristimo misleći na alternativnu, avangardnu književnost.

[2] Tekstovi pisaca beat-generacije žene uglavnom prikazuju kao konvencionalne pristalice uvriježenih domaćih vrijednosti, ali i kao promiskuitetne buržujke, smatrajući ih seksualiziranim objektima koje nazivaju chicks (Carden 2).

[3] Roseanne Giannini Quinn je, primjerice, napisala: „Beatnički književni pokret sa sigurnošću možemo nazvati maskulističkim", (19).

[4] Još šire, Kurt Hemmer u svojoj Encyclopedia of Beat Literature pisao je o izuzetnoj beatničkoj inkluzivnosti te primijetio i kako su beatnici nastavili utjecati i na generacije rock-glazbenika stasale nakon šezdesetih godina 20. stoljeća, naglasivši njihov izniman utjecaj na pop kulturu: „U sedamdesetima Lou Reed, Patti Smith i njujorška punk-scena isticali su Burroughsa kao svog počasnog oca. U osamdesetima članovi sastava The Clash nastupali su s Ginsbergom. Tijekom devedesetih Kurt Cobain surađivao je s Burroughsom. Naposljetku, Black Rebel Motorcycle Club nazvalo je jedan od svojih albuma Howl u čast Allenu Ginsbergu (xi)." Nemoguće je, dakle, u ovom kontekstu ne spomenuti izuzetnu beatničku inkluzivnost, pa čak i njihov veliki utjecaj na druge kulture, o čemu također piše Kurt Hemmer: „Ako pogledamo dovoljno pažljivo, pronaći ćemo beatnike u gotovo svim aspektima života: muškarci i žene, gay, straight, biseksualni i aseksualni; demokrati, republikanci, anarhisti, socijalisti i komunisti; bijelci, afroamerikanci, latinoamerikanci, azijati i predstavnici još tuceta država uz Sjedinjene Američke Države. Ne mislim da bilo koji drugi umjetnički pokret ima toliki stupanj inkluzivnosti koliki ima beatnički pokret (xii)." Kako onda uopće možemo pomisliti da beat-generaciji nisu pripadale i žene?

[5] Gotovo kao izuzetak koji potvrđuje pravilo, Diane di Prima spomenuta je u kasnom izdanju klasične The Norton Anthology of Literature by Women (1985.) autorice Sandre Gilbert. Niti jedna beatnička autorica nije uvrštena, primjerice, u No More Masks: An Anthology of Twentieth-Century American Poets (1993.) urednice Florence Howe, niti u Coming to Light: American Women Poets in the Twentieth-Century (1985.) urednica Marylin Yalom i Diane Middlebrook.

[6] Ova austrijska pjesnikinja rođena u Njemačkoj kao svjedokinja holokausta svoje neslaganje s nacističkom ideologijom izrazila je odbijajući prihvatiti pravila svojega materinjeg jezika te je 
inzistirala pisati svoje ime i prezime malim početnim slovima. Riječ je o simboličnom protestu protiv „zakona i reda”, tim više što se u njemačkom jeziku sve imenice pišu velikim početnim slovom (Hemmer, Encyclopedia 340-341).

[7] Druga generacija beatničkih spisateljica u kontekstu ovoga rada značajna je jer s jedne strane prethodi, a s druge čak i navješćuje drugi val feminizma, ženski pokret aktualan šezdesetih i sedamdesetih godina dvadesetog stoljeća (Johnson, „Mapping” 17).

[8] Ne smiju nas zavarati imena iz svijeta glazbe i pop-kulture. Bob Dylan dobitnik je Nobelove nagrade za književnost 2016. godine, a i svi ostali umjetnici s popisa također imaju značajan književni i pjesnički opus.

[9] Sada je jasno zbog čega se knjiga Ronne C. Johnson i Nancy Grace zove Breaking the Rule of Cool.

[10] Tako je primjerice di Prima imala petero djece četvero različitih očeva raznolikog etničkog i rasnog nasljeđa, Jones je bila u rasno miješanom braku iz kojega je imala i djecu, Frazer je, u nastojanju da pomogne obitelji, pribjegla prostituciji i svoje dijete dala na posvojenje, a Johnson je bila ono što se danas naziva samohranom majkom (Johnson, „Mapping” 26).

[11] Riječ je svakako o manje poznatim radovima i naše, prostorom ograničene osvrte na svaki od radova u daljnjem tekstu treba čitati manje kao analizu, a više kao preporuku za čitanje.

[12] Glavni likovi romana zamijenili su ustaljene uloge dobivajući na kraju ponešto od suprotnog svijeta. Susan je dostigla muško beatničko stanje stavom prezira prema institucijama, dok je Peter na kraju romana u svojevrsnom ženskom stanju uskraćivanja, u ovom slučaju, slobode užitka.

[13] Di Prima ovo radi prilično eksplicitno i doslovno: „My cunt a bomb exploding” (85). Cijela pjesma u znaku je naglašeno seksualnih metafora ženskog tijela, dakle onoga što je privatno i taboo, no u svrhu stvaranja oružja, dakle nečega što u ratu postaje vrlo javnim interesom.

[14] Duboko poštovanje bilo je obostrano pa je Allen Ginsberg Anne Waldman nazvao „duhovnom suprugom” (citirano u Puchek, „From Revolution” 237)

[15] Na tragu njezina zanimanja za antropologiju. 
[16] Engl. chant. Maria Sabina pjevanje je izvodila pod utjecajem psihodeličnog i beatnicima dobro poznatog peyotea.

[17] „Poezija nastala ne iz jezika ili opažanja, već iz pokreta: poezija plesa koja ističe zvukove i ritmove jezika i seksualnosti” (Puchek, „Semiotics” 41).

[18] Već izvorne riječi pjesme, uostalom, kažu: „all the world fits in my mouth / I’m the multipleuniverses woman” (Puchek, „From Revolution” 240).

\section{(c) $($ ) (3)}

Creative Commons Attribution-NonCommercial-NoDerivatives 4.0 International License 